\title{
O PEDAÇO Da Minha Roupa ÍnTima
}

Geraldo Cebola João Lucas $^{3}$

Quando a sociedade me germinou, colou o termo Chapantsi como nome em mim. O significado de Chapantsi é coisa da terra. Fui parido num pedregulho que dorme e adorna o chão dos Mwene - título de poder para os chefes do Estado de Monomotapa - um chão proibido de se estender em demasia pelos rios Mazoe e Luia. Meu aleitamento materno resistiu apenas duas semanas por recomendações das espíritas nyúngues da minha terra. Segundo as espíritas, eu era bebé de se alimentar de leite de ovelha.

Foi arquitectada uma cerimónia de contentamento por eu ter consumido dois anos de vivente na terra. Há um banho, que é ritual de conterraneidade, em que homens e mulheres dançam. Dançam divorciados de qualquer tipo de veste, dançam com o corpo original, apresentando apenas aquilo que são dádivas corporais que a natureza nos oferece como desanimais, ou melhor, como humanos. Eu recebi tal banho, uma espécie de antibala, de antídoto contra males que possam advir de outros espíritos estrangeiros ou desavizinhados por qualquer contradição. A água do banho ervático era turva. A sua turvice não residia na sujidade, mas no elevado nível de mistura ervática - raízes, tubérculos, penas e uma miscelânea de venenos para cozer o corpo e para propor aos músculos capacidade de defesas futuras. Uma mistura à pandza-um ritmo musical jovem de Moçambique.

3 Professor da Universidade Pedagógica - Delegação do Niassa - Moçambique. 
$\mathrm{Eu}$, ainda ínfimo em idade, captava aquelas melodias virgens. As senhoras açoitavam-me com seus mamilos, os homens encardiam-me com o sal e o vinagre do calor que escorria de seus machos músculos. As espíritas deformavam minha pele com marcas, tatuagens e outro tipo de cortes e me salgavam as feridas com um tempero de cores indefinidas, cores de veneno.

-Nem a fome o consumirá, dizia a tribo dos homens cerimonialistas.

A mega-cerimónia consumiu duas semanas. O solo estava cansado de tanto ser pisado. Os pássaros que se tinham desavizinhado das árvores que adornavam o aldeamento emitiam chilreares de protestos. $\mathrm{O}$ pedregulho que não consumia raios solares havia quinze dias, mudava de cor e semblante. As gargantas do departamento feminino que animava as melodias se encontravam já saturadas e familiares. Os timbilistas apresentavam mãos gordas de inchaço. $\mathrm{E}$ meu corpo, meu corpo demasiado fértil de drogas e outros consumíveis que foi sugando dizia -basta!. A cerimónia foi encerrada por quilolitros de chuva, parecia nascer outro rio diferente do Mazoe e do Luia no aquém da Terra. Era sinónimo dum abençonhamento, uma espécie de purificação. Era uma resposta dos deuses chapantsis, dos nossos directos antepassados.

O meu desenvolvimento parecia-se com a natureza. Os tons da voz se empurravam e se substituíam; o peito ganhava contornos; os membros se irisavam; as rugas e tendões tesavam. Estes saltos desenvolvimentistas simbolizavam meu crescimento e divórcio com a infantilidade. Eu já era convocável para caça, pesca, e segredos cerimoniais.

Introduziram-me à escola. Aprendi a ler e escrever. Minha caligrafia nunca passou da falta de jeito, minha leitura não fugia do gaguejo. Já na sexta classe odiava meu professor de Matemática. Um dia desses pedi ao professor para que resolvesse os meus afazeres de casa. A direç̧ão da escola convocou meu pai para uma reunião de emergência disciplinar. $\mathrm{O}$ director, um homem magro e de nariz torto, promulgou a minha descontinuidade na escola por ser órfão de disciplina - meu comportamento não 
se amigava com os princípios da catedral pedagógica. Meu pai se riu de desgosto. A quisência de meu pai seria bater-me, mas a recomendação dos Srikiros inibia-o de fazê-lo. Abracei-o entupido de compaixão, quase que o esmagava sobre meu peito.

-Filho, chiou meu pai, -não me estilhace.

Só depois de tê-lo expulso dos meus braços é que notei que meu aperto tinha ganho excessividade gravítica. O velho estava sem ar e com o peito encolhido, importou oxigénio por uns instantes, fumou a paisagem e tossiu com estrondo - sinal de recuperação dos ânimos.

-Pai, resmunguei, isso de escola não épara mim. O que sonho nas viagens nocturnas está ligado a um curso de guerra. Meu indestino é escola, e meu destino é comandar ou lutar contra mantsangas.

Eu gostava de ouvir histórias que difundiam e popularizavam a coragem de Mutota; Caprazine; Matuzianhe e outros nomes que tombaram em defesa do pedaço de terra que me viu a germinar. Vezes sem conta era visitado por uma figura imaginária, de músculos tesos, olhos de visão longitudinal, de pele carregada a escuro; quando falava, exibia dicções carregadas de características linguísticas do shona - língua falada no Planalto do Zimbabwe e parte de Moçambique.

-Deve ser Mutota, dizia meu pai.

Fazia dezassete anos. O calor era escaldante em manhã de sábado, sinal de anúncio duma chuva próxima. Me aproximei dum quartel da zona a fim de me alistar. Os militares recepcionistas engordaram de admiração. Muitos jovens fugiam o serviço militar porque era tempo de guerra intensa entre a RENAMo e o governo da Frelimo. Morria-se, saqueava-se, emboscava-se e roubava-se. O toque da bala havia muito que tinha ganho o troféu de melodia mais escutada em detrimento da melodia das aves e do ritmo harmónico da natureza em geral. O canto madrugador do galo, também, há tempo bastante que era antecedido e por vezes substituído por balas dum ataque madrugador ou pelo estrondo dum morteiro sa- 
cudido em regiões vizinhas. Por fim me alistaram e prescreveram que eu aguardasse.

Participei a meu pai o meu alistamento:

-Pai, serei nyakhondo, homem de guerra.

Meu pai fingiu não ouvir e fixou o olhar nas alturas, engoliu dois goles de ar como se estivesse a fumar vozes. Suas orelhas estavam hirtas e em choque de íman. Seu rosto expressava tristeza e alegria, uma espécie de mistura química - soma de reagentes: pó de contentamento por notar que eu era homem decidido e capaz de perpetuar a coragem dos meus antepassados e pó de entristecimento por estar prestes a divorciar-me da sua custódia.

-Terás sorte, resmungou tia Kambuma no acto da entrega, aquando dos meus quinze anos.

Minha cueca foi enviada ao swikiro Nyandebvu.

-Parabéns meu filho, disse depois de recuperar a voz que se havia refugiado no ventre. -Irás partir, mas primeiro trataremos da sua cueca conforme as regras mwene.

Minha cueca, tanga preferida, cueca que me emprestava estilo, era a cueca branca. A cueca branca fora-me oferecida por uma tia materna, tia espírita - a tia Kambuma - como presente de aniversário. Tia Kambuma vivia por cima dum pedregulho no centro das águas do rio Mazoe. $\mathrm{O}$ pedregulho que assegurava a casa da tia Kambuma era uma espécie de ilha, para alcançar a casa da tia devia-se usar a canoa ou mesmo ir a nado para quem pudesse e não temesse os jacarés que passeavam e exibiam seu charme pelas águas turvas e violentas do Mazoe.

- A música do Mazoe vem do melhor jazz do mundo, seu violino é o tapete de pedra e suas cordas são as correntes de água, dizia tia Kambuma. Ela contava que recebia visitas nocturnas dos swikiros mais antigos, estes transmitiam segredos de peso enorme. Contava que geralmente, os defuntos apareciam nus para mostrar naturalidade e lealdade e ajudavam-na a predizer, prever e prevenir acontecimentos do tempo vizinho. O Mazoe, 
este era igual a si mesmo, absorvendo calores, oferecendo sombra e lugar para cerimónias, distribuindo beleza à paisagem e fornecendo vida aos animais da região. Minha tia, Kambuma, contava que não só ela conversava com o Mazoe, assim como o Mazoe conversava com o Luia. O Luia e o Mazoe combinavam e acordavam sobre as formas de defesa da minha terra, a terra dos Mwene. Uma vez, de madrugada fria, tia Kambuma surpreendeu os dois rios a combinarem uma greve de seca na parte sul para não permitir que houvesse água para os matsangas daquela região.

Nyandebvu trabalhou a cueca para servir defesa. Minha cueca, agora, era cueca de poderes, gorda de mistérios. Meu pai baptizou-a de cuetanga- cueca + tanga. Com a cuetanga, segundo meu pai, eu estava seguro e arrumado para dignificar o nome de meu país e dos mwene.

Os treinos começaram à rajada. Meus músculos se tornaram mais espertos que antigamente. Se cantava durante a marcha. As punições, no caso de falta às regras, eram severas. Recordo-me duma vez em que Mbalamezinho, meu camarada de formação militar, desmaiou antes de se lhe anunciar qual seria sua punição por ter cumprimentado uma garota que se locomovia nas bermas da estrada em que nos encontrávamos a marchar. $\mathrm{O}$ treino era extenso e intensivo; para além dos instrutores havia os coinstrutores. Os coinstrutores cuidavam de furtar as nossas merendas, mantas e roupa. Os 45 dias de formação foram suficientes para conquista de nova identidade: um msodja, um mtropa - significando militar ou homem de guerra. Mas, para meu pai, eu era chikunda - guerreiro típico do Vale do Zambeze.

Sob força duma ordem militar superior, fui encomendado para a região de Chicualacuala - sul de Moçambique. Por meio dum Antanove, andamos por cima da terra. $\mathrm{O}$ aparelho despejou-nos num ervaporto vizinho do rio Limpopo. Éramos quatro musodjas.

A ordem era caminhar até Chicualacuala. Dois coparticipantes da missão faleceram. Um, o Candodo, morreu fustigado por sede e malária. Guardamo-lo debaixo da terra. A cerimónia foi rápida, acompanhada de pai-nosso mal decorado. O Zé-padre é quem ministrou o acto. Trazia 
duas páginas do livro do Levítico. Zé resmungou em leitura de dois versículos e conduziu-nos ao pai-nosso.

Dia seguinte morreu o nosso sacerdote, o Zé-padre. Beijado por uma vespa preta, não resistiu ao beijo feroz do insecto. Colei as páginas do Levítico sobre seu peito. Minha prece em reconhecimento do recente defunto foi pouco nostálgica. Percorri os ancestrais, pedindo-lhes para que o recebessem no pomar das almas falecidas, lá onde os fantasmas se concentram e discutem estratégias de desabitação dos vampiros, lá onde desenham escalas de visitas nocturnas aos que se encontram no mundo dos vivos, adiando a morte.

Resolvendo os noves-fora dos sujeitos, notei que restávamos eu e o Tinga. Na manhã do terceiro dia, resolvemos plantar nossos corpos numa sombra de mafura, planta típica do sul de Moçambique. Subtraímo-nos da vida, viajando pelo sono como estratégia de espremer a carga de sono que havia imigrado para nossos corpos. Os organismos desligaram-se; os cérebros deslocaram-se; os estômagos contraíram-se. Eu me sentia como se tivesse retirado meu esqueleto do corpo para pendurá-lo na prateleira duma oficina. Da profundidade do sono eu arrancava uma martelada sobre a composição do esqueleto. Eu estava a ser consertado: o sono é o melhor mecânico do corpo humano.

Quando me revoltei do sono, o sol já surgia das plantas, sorridente. Acenei para ele e mandei cumprimentos aos do lado de lá. Perdemo-nos pela mata dentro. Às sete horas do dia seguinte conseguimos visualizar o lugar para onde emigrávamos. A duzentos metros sofremos uma emboscada de sete minutos. -Era recep̧̧ão, comentou o comandante.

A religião militar ordenava que seus crentes se concentrassem no começo do dia. Trovejei da cancela para o rectângulo de formatura. Alonguei o pescoço para binocular meu comparsa de origem. Nada. Meu coração balançou. Arrastei-me à fila e fiquei disciplinado. -Mas onde estará o Tinga!? murmurei de mim para mim. Depois de muitos "esquerda-ires e direita-ires", começou o discurso do comandante: 
- Aqui, na unidade de Chicualacuala recebemos dois vermes. Um não se adaptou às transformações da natureza, caiu na previsão de Charles Darwin, pereceu seco de asfixia. Os vermes vieram atrapalhar o nosso trabalho, as nossas patrulhas e o nosso povo. O verme que ficou veio nos espiar; já não comeremos carne de vaca à vontade; já não teremos comidas extraídas das colunas liberalmente.

Meu coração sangrava de dó e dor. A notícia da morte de meu amigo fuzilava-me os sentidos. Mas chorar de militar é avolumar coragem. Fui forçaconvidado a ir para frente da formatura, lugar do comandante, com o intuito de ser apresentado. Arrastei-me até lá, todo órfão de ânimo e a beijar dona tristeza que se encontrava adentrada no convento do meu peito. Já junto de onde estava monumentado o comandante, este recomeçou com o discurso:

- Estão a ver este verme? Veio lá do centro de Moçambique, duma terra que a Geografia desconhece. Ele é destas espécies impróprias para o exército.

Os militares me fulminavam com os olhos. Quando terminou o ritual emigrei rapidamente para a cancela. $\mathrm{Na}$ gíria local tudo era cancela - desde a guarita até o dormitório.

- Amigo! Aqui é assim, o anormal é que se torna ético, desaloje parte do seu reportório moral.

Como antídoto da dor, preferi enterrar-me nas mantas. Sonhei com meu pai e minha tia. Vestidos de peles de leopardo e de flechas na mão. Meu pai emitia gestos surdos. Em sonho, minha tia sobrevoou comigo o rio Save, o rio Buzi, o rio Gorongosa, passamos do parque de Gorongosa, cortamos o Púnguè, cortamos a Serra Choa até ao rio Luía e sentou comigo na varanda da sua casa-ilha. Sobre a fúria das águas, fez-me recordar da cueca - minha cuetanga.

- Meu filho, nunca se divorcie da cueca.

Quando despertei, era hora de formatura. Quando me divorciei das cerimónias matinais fiz-me à rua. A notícia da minha chegada a Chicualacuala já havia incendiado a aldeia. Não havia quantidade de água 
que pudesse mitigar a sede de curiosidade que castigava os chicualenses. Fui errando os passos pelos becos. Eu precisava conversar, expulsei um cigarro tradicional do meu bolso e ataquei-o com o fósforo. Enquanto chamineava o ar com o fumo do cigarrão, me distanciava do cenário do quartel. Aquele quartel, onde a desordem é ordem, onde a ausência de lógica é a própria lógica, parecia um campo de refugiados de guerra, mas não duma guerra entre homens. $\mathrm{O}$ cenário era similar ao resultado duma guerra entre o exército do Diabo e de Deus. Uma guerra em que os fiéis já do mundo dos defuntos reapareceriam para mostrar lealdade - uns a Deus e outros ao Diabo.

Amontoei-me na perspectiva de dar os puxões finais ao meu cigarro e cumprimentar os espíritos. Orei na minha língua materna em comunicação com defuntos. Minutos depois perdi meu olhar pela mata dentro: saudade de caça, nado e pesca.

- Estás triste? soou uma voz em acórdãos; a voz era feminina e felina. Confesso que tive arrepio. Depois segurei-me.

- Quem és? indaguei.

- Helena. Mas podes me chamar por Rirandzo, se for da sua quisência. Rirandzo significa amor de Deus, dos homens, amor com as plantas assim como com o meio - é amor. E a vida, apesar de toda a amargura que a acompanha, ela é rirandzo. A fonte da dialéctica da vida está no rirandzo, o amor é como um rio cuja fonte é inesgotável.

- Pensas assim? indaguei.

- Se penso? ripostou. - Eu creio, e verifico que é assim. Na sua terra Chapatsi, as coisas não são assim? Não te assustes, eu sei que és Chapatsi, o novo da aldeia. E que deves estar triste com a morte do seu comparsa, o Tinga.

A Rirandzo, esta mulher era linda, penetrante e simples. Sua sabedoria empírica sobre o amor dificultava minha filosofia. Minha escola de raparigas tinha sido curta e machista. A sombra que nos cobria era de cajueiro. Rirandzo esqueletou-se e entregou-me uma fruta do cajueiro. Aquela fruta sabia a rirandzo. Os cajueiros dão belenas/rirandzos - pensei. 
Sua cintura dançava ao sopro do vento. Eu saltitava de ansiedade, não sei de quê (!). Geograficou sua casa e intimou-me a comparecer no fim do dia, caso me conviesse.

Noite dentro perfumei-me com o óleo de mafurra e, clandestinamente, munido da minha arma, transportei-me para a habitação de amor - casa de Rirandzo. Alegrava-me o facto de estudar o discurso sintético de Rirandzo. Historiograficou a região com selos e símbolos. Quando expliquei o significado de Chapatsi, segredou o seguinte: -Tu és da Terra e eu sou da Alma. Assim tu pertences ao solo e eu ao espírito, ao celestial. Você e eu somos um casamento de encontro.

Viajei meu corpo para junto dela e larguei-me para os braços dela e magnetizamo-nos em beijos. Proibi-a de tirar-me a cueca. Minha cuetanga não é tirada nem lavada. Expliquei os motivos tradicionais e identitários da minha terra.

$\mathrm{Na}$ madrugada daquela noite, rebentou um ataque do inimigo. As balas provinham de tudo o que era canto. $\mathrm{O}$ inimigo estava em número de cogumelo. Reboquei a Helena e atirei-me ao vão. Aos tiros e em fúria retirei a Helena da aldeia e deixei-a num esconderijo com ordens de nunca sair sem meu sinal do lugarejo. Saí da habitação da Helena sem calças nem camisa, apenas de cueca. Orei e caí possesso pelo espírito mpondoro - típico dos mwenes. Penetrei no ventre do quartel aos tiros e subtraí o comandante daquela prisão de balas. Fui depositar o comandante num buracão que distava a 400 metros da aldeia e voltei para o combate. $\mathrm{O}$ ataque só terminou às sete horas da manhã. Do quartel só restavam ruínas. Da aldeia, apenas cinzas. Dos mortos contavam-se populares, militares governamentais e matsangas. Dos 200 homens, apenas 9 tinham negado a morte.

Uma semana depois recebi congratulação do Ministério e pedi meu regresso a Mazoe, terra do meu ser. Eu e Rirandzo voltávamos juntos. 